\title{
Entrepreneurial Competencies and Performance of Informal Micro-Enterprises in Malaysia
}

\author{
Abdullah Al Mamun ${ }^{1^{*}}$ \\ Perasna A/P Subramaniam² \\ Noorshella Binti Che Nawi ${ }^{1}$ \\ Noor Raihani Binti Zainol ${ }^{3}$ \\ 1 Senior Lecturer, Faculty of Entrepreneurship and Business, Universiti Malaysia Kelantan \\ ${ }^{2}$ Graduate Student, Faculty of Entrepreneurship and Business, Universiti Malaysia Kelantan \\ ${ }^{3}$ Senior Lecturer, Faculty of Entrepreneurship and Business, Universiti Malaysia Kelantan \\ *Corresponding Author, Email: abdullah.a@umk.edu.my
}

\section{Doi:10.5901/mjss.2016.v7n3p273}

\section{Abstract}

\begin{abstract}
Literature on informal economic activities has identified the significant role of informal micro-enterprises in national development and the role of entrepreneurial competencies in micro-enterprise performance. This study, therefore, examined the role of entrepreneurial competencies, i.e., risk-taking propensity, need for achievement, self-efficacy, and experience in informal micro-enterprise performance in Kelantan, Malaysia. This study used a cross-sectional design and collected quantitative data from 197 informal micro-entrepreneurs. Findings of the path analysis using variance-based structural equation modeling (SEM-PLS) revealed that informal micro-entrepreneurs' risk-taking propensity and self-efficacy have a significant positive effect on micro-enterprise performance. Development programs and policies should, therefore, focus on increasing low-income informal micro-entrepreneurs' self-efficacy and ability to take risks in order to take advantage of all the incomegenerating opportunities available to them, which would ultimately lead to the improvement of the socio-economic condition of low income households in Malaysia.
\end{abstract}

Keywords: Entrepreneurship; Competencies; Enterprise Performance; Informal Economy

\section{Introduction}

An informal economy consists of economic activities that occur outside of the formal institutional boundaries but which remain within the informal institutional boundaries for large societal groups, that are engaged in low-paid employment as waged employees (Webb et al., 2013). These persons are labeled as informal entrepreneurs who display entrepreneurial attributes, qualities, and traits (Webb et al., 2013; Williams and Gurtoo, 2011). The informal economy exists in both developing and developed nations, though it is most often connected as an engine of economic dynamism in developing countries. Generally, the examples of the informal economy include workers operating as street vendors, construction workers, and unlicensed taxi drivers. Specifically, this informal economy denotes all unregulated and non-formal economic activities and it is characterized by low entrance requirements in terms of capital and qualified workers, small scale operations, and labor intensive methods of production and technology. Often, informal businesses are small and family-run or run by a single entrepreneur.

There are wide ranges of definitions of informal economic activities. Among them, Tokman (2001) noted that in developing countries, there are often no clear distinctions between formal and informal sectors; large factories and staterun enterprises have informal labor forces working beside their formal counterparts. Meanwhile, Djankov et al. (2002) defined informal economy as an activity of an unofficial business (e.g. unreported employees and unregistered businesses) to make it part of the formal sector. In addition, Amurane (2007) defined the informal sector as an area where the people start their businesses (voluntary or involuntary and illegal) and they are, obviously, not registered. In Malaysia, informal traders are not registered with Companies Commission of Malaysia (Suruhanjaya Syarikat Malaysia), as they do not have any permanent business premises. Instead, informal traders registered with the local municipal council (i.e., Majlis Perbandaran, Kota Bharu), where they pay RM20-RM36 per year depends on where they located their 
business. Informal traders in Malaysia also have to pay RM3-RM5 daily to local municipal council for cleaning the business premises.

Earlier studies have noted a significant proportion of workers from low-income households being involved in informal economic activities (Naik, 2009; Sibal, 2007; Department of Statistics Malaysia, 2013). A study by Naik (2009) indicated that the number of informal sector workers in India from 2004 to 2005 was 394.9 million and this figure contributed to $86.3 \%$ of total workers there. Nevertheless, Sibal (2007), in the Philippines, reported that the portion of the informal economy had declined from $57.6 \%$ in 1980 to $49.6 \%$ in 2005 . This is due to the new policy where some of the members were offered jobs in the formal sector as non-regular or contractual employees. In Malaysia, the total workforce in 2013 was 13.2 million; among them, 1.3 million (9.7\%) were involved in the informal sector (Department of Statistics Malaysia, 2013). Based on a survey conducted by the Department of Statistics Malaysia (2013), people who live in urban areas were recorded as the biggest population to be involved in the informal sector (814,700 people) in 2013 , and no gender difference was recorded for those who were involved in the informal sector. However, the numbers in the female group of those involved in the informal sector was higher in 2013 compared to 2012. In terms of the age groups, the 40 44 age group (180,000 person) and the $45-49$ age group (178.400 person) were the main group in the informal economy. The report showed that 817,200 persons with secondary education represented the highest group of those involved in this sector and the own-account worker was the biggest employment group in the informal sector in 2013. Many people were involved in the construction industry followed by wholesale and retail trade, repairing vehicles, manufacturing, and service and sales workers; these were recorded as the main categories of occupation in the informal sector. Among the 15 states in Malaysia, Selangor recorded the highest percentage of employment in the informal sector (15.2\%), followed by Johor (11.8\%) (Department of Statistics Malaysia 2013).

It is evident that a significant proportion of micro-entrepreneurs in Malaysia are currently operating in the informal economy. Most of the development programs and policies for the socio-economic development of low-income households in Malaysia are focused on formal micro-entrepreneurs. It is difficult for informal micro-entrepreneurs to access working capital and other supportive services. The entrepreneurial competencies of informal micro-entrepreneurs, therefore, can have a significant effect on micro-enterprise performance. Entrepreneurial competency commonly refers to the capability of completing something by using resources. According to Mitchelmore and Rowley (2013), entrepreneurial competencies are referred to a specific group of competencies relevant to the activities of a successful entrepreneurship. The same view was shared by Man et al. (2002), who defined entrepreneurial competencies as those involving the roles played by the entrepreneurs successfully. Bird (1995) explained that entrepreneurial competencies are best defined by all the characteristics such as motives, self images, social roles, traits, and specific knowledge that lead to the birth, survival, and growth of the business.

An entrepreneurial competency is a most needed value for an entrepreneur. The entrepreneur should always have personal competencies, which refers to important personal qualities and abilities that help in the building up of personal strength and in enhancing an individual's effectiveness in performing certain challenging tasks such as managing one's own business (Man and Lau, 2000). According to Andrews et al. (2011), it is necessary to recognize the characteristics of the entrepreneur in informal activities, in order to explain the business success or failure based on the various characteristics of the entrepreneurs. The characteristics are an interaction with contingency factors of the informal economy in which the entrepreneur operates and chooses the strategy. This study is, therefore, designed to examine the role of entrepreneurial competencies, i.e., risk taking propensity, need for achievement, self-efficacy, and experience in informal micro-enterprise performance in Kelantan, Malaysia.

\section{Literature Reviews}

The informal economy or the informal sector is considered by the International Labor Organization (ILO) as the provision of subsistence to families (Andrews et al. 2011), which focuses more on the nature of employment in addition to the characteristics of enterprises, which include informal employment both within and outside the agricultural sector (Gerxhani, 2009). These definitions are largely consistent with Nitcher and Goldmark's (2009) economic activities as those that are unregistered and illegal but yet produce legal products. The informal economy is portrayed by Williams and Gurtoo (2011), as unwilling and unfortunate pawns within an exploitative global economic system in which work is becoming ever more precarious and poorly paid. Entrepreneurial activities are important to the economic growth and development of nations, in which the activities are embedded in informal and formal economies.

In regard to entrepreneurial competencies, Mitchelmore and Rowley (2013) noted that entrepreneurial competencies could lead to a better enterprise performance and growth and also economic development. Churcill and Lewis (1983) suggested that entrepreneurial competencies have the potential to, in turn, drive business growth. Man et 
al. (2002) identified ten dimensions of competencies, which are opportunity, relationship, analytical, innovative, operational, human, strategic, commitment, learning, and personalities. All these dimensions are expected to have positive impacts on SME performance. According to Ahmad, Halim and Zainal (2010), entrepreneurs nowadays are responsible for many roles and activities compared to the managers. They need to be engaged in various roles such as in managerial, entrepreneurial as well as functional roles. Many prior scholars focus on entrepreneurial competencies' impact on business performance, specifically, Brinckmann et al., (2011), Man and Lau (2000), and Lerner and Almor (2002) who conducted their studies on entrepreneurial competencies focused on developed economies. A recent study by Mitchelmore and Rowley (2013) examined competencies of female entrepreneurs who are committed to the growth of their businesses. They identified that personal and relationship, business and management, entrepreneurial, and human relation competencies are the four main clusters of competencies. Based on earlier literature on entrepreneurship and SMEs, it is evident that entrepreneurial characteristics play an important role in ensuring business success, such as individual characteristic, personal traits, entrepreneur orientation, and entrepreneur readiness (Islam et al., 2011; Webb et al., 2013). Details about the selected key competencies and how they can affect informal enterprise performance are noted below.

\subsection{Risk Taking Propensity}

According to Tull (2009), risk-taking refers to someone who is involved in a certain situation that is either good or harmful, hoping that at the end of it, she/he can get a positive result. However, Landqvist and Stalhandske (2011) believed that the risk-taking propensity should be well conceptualized and well defined as a person's direction towards a decision-making situation. Zhao et al. (2010) conducted a study to predict the factors that influenced entrepreneurial intention in doing business. Their finding indicated that risk propensity is the top predictor of entrepreneurial intentions. In contrast, the finding by Zhao et al.. (2010) indicated that risk taking propensity had no impact on business performance, even though Shepherd (2003) stressed that risk taking is known as a factor that can drive a firm's performance. A recent study by Willebrands, et al. (2012) further explained that entrepreneurs should not solely take risks without considering the effects in the future. Informal micro-entrepreneurs' ability to take risks, in order to take advantage of short-term incomegenerating opportunities can, therefore, lead to a better micro-enterprise performance.

\subsection{Experiences}

Shepherd et al. (2000) noted that experience could be gained when people are directly or indirectly involved in an event, and they can gain knowledge from the event. One of the abilities that entrepreneurs should have is relevant experience. Relevant experience is required in order to manage, formulate, and handle all the processes to ensure that there is business success and growth. Fernald et al. (2005) examined separate literatures on entrepreneurship and leadership, and derived a set of similar "characteristics" common to both leaders and entrepreneurs' aims. As noted earlier, most of the informal micro-entrepreneurs lack access to working capital and enterprise development training. For many of them, relevant work experience can be the only way for gathering the necessary skills to manage a micro-enterprise on their own. This study, therefore, examined the effect of relevant work experience on informal micro-enterprise performance in Kelantan, Malaysia.

\subsection{Need for Achievement}

Among the psychological and behavioral characteristics, the need for achievement is considered as one of the leading motivating factors contributing towards enterprise performance. Need for achievement refers to the expectation of doing something better or faster than anybody else or better than the person's own earlier accomplishments (Hansemark, 2003). The need for achievement was found to be higher among small business owners while assessing their entrepreneurial orientation (Sagie and Elizur, 1999). Different studies conducted on entrepreneurs and non-entrepreneurs show that the need for achievement has a strong relation with entrepreneurship (Hansemark, 1998; Yosof et al., 2007). As for informal micro-entrepreneurs, the motivation to give their best can be directed from their need for achievement. This study, therefore, examined the effect of informal micro-entrepreneurs' 'need for achievement' on micro-enterprise performance in Kelantan, Malaysia. 


\subsection{Self-Efficacy}

Self-efficiency is a useful concept for explaining human behavior as research has found that it is one of the influential roles in determining an individual's choice, level of effort, and perseverance (Chen et al., 2004). Entrepreneurial selfefficacy also refers to the strength of a person's belief that she/he is capable of successfully performing the various roles and tasks of entrepreneurship in either the formal or informal economy sector. As a task oriented behavior, entrepreneurial self-efficacy can be defined as the entrepreneurs' beliefs and confidence in their capabilities to affect the environment and to be successful in implementing entrepreneurial behaviors (Luthans and Ibrayeva, 2006). Man and Lau (2000) stated that personal competencies refer to the physical and mental abilities of an individual in facing challenging tasks. This includes self-efficiency and emotional intelligence (Thompson 1998), self-motivation (Martin and Staines 1994), and self-management (Winterton 2002). It is, therefore, expected that informal micro-entrepreneurs' level of selfefficacy would have a positive impact on micro-enterprise performance in Kelantan, Malaysia.

\section{Research Methodology}

This study uses a cross-sectional design to examine the effect of entrepreneurial competencies on the performance of micro-enterprises operating in an informal economy in Kelantan, Malaysia. The population definition was based on the definition of an informal micro-enterprise, which is not registered with Companies Commission of Malaysia (Suruhanjaya Syarikat Malaysia), as they do not have any permanent business premises. Informal traders registered with the local municipal council (i.e., Majlis Perbandaran, Kota Bharu), where they pay RM20-RM36 per year depends on where they located their business. This study used convenience sampling method and collected data from the 'night markets' (pasar malam) where most of the informal micro-entrepreneurs operate. Data was collected from 197 selected microentrepreneurs.

\subsection{Research Instrument}

The questionnaire was designed using simple and unbiased wordings whereby respondents can easily understand the questions and provide answers based on their own perceptions. Questions were adopted from earlier studies with minor modifications where needed. The five-point Likert scale of 1 to 5 points (strongly disagree, disagree, neutral, agree, and strongly agree) was used for the independent and dependent variables.

\subsection{Data Analysis Method}

PLS-SEM is a causal modeling approach aimed at maximizing the explained variance of the dependent latent constructs (Hair, Ringle and Sarstedt, 2011). Due to the exploratory nature of this study, together with the relatively low sample size and non-normal data, this study used the variance-based structural equation modeling, i.e., partial least squares (SEMPLS) estimation with the primary objective of maximising the explanation of variance in the structural equation model's dependent constructs. The findings of this analysis were reported as recommended by Hair, Ringle and Sarstedt (2013) for PLS modeling. These include the (a) indicator reliability (e.g., standardized indicator loadings of 0.70 ; in exploratory studies, loadings of 0.40 are acceptable); (b) internal consistency reliability (Cronbach's alpha and composite reliability both measures should exceed 0.70); (c) convergent validity (AVE $\geq 0.50$ ); (d) discriminant validity (Fornell-Larcker criterion results and/or cross loadings); (e) $r^{2}$ (acceptable level depends on the research context); (f) effect size or $f^{2}$ $\left(0.02,0.15,0.35\right.$ for weak, moderate, strong effects); (g) path coefficient estimates; and (h) predictive relevance $Q^{2}$ and $q^{2}$ $\left(Q^{2}>0\right.$ is indicative of predictive relevance; $q^{2}: 0.02,0.15,0.35$ for weak, moderate, and strong degree of predictive relevance of each effect).

\section{Summary of Findings}

\subsection{Characteristics of Respondents}

To measure the effect of key entrepreneurial competencies on micro-enterprise performance, this study collected data from a total of 197 informal micro-entrepreneurs from selected local floating markets. Entrepreneur's demographic characteristics, as noted in Table 1, show that the proportion of male and female micro-entrepreneurs is almost equal. More than $50 \%$ of these entrepreneurs are less than 30 years old indicating that a large number of young low-income 
people are currently engaged in informal economic activities in Malaysia. Among the informal micro-entrepreneurs, $60.9 \%$ of them are Malay, $30.5 \%$ Chinese, $2 \%$ Indian, and $6.6 \%$ others. Among the respondents, $35 \%$ are single, $49.74 \%$ married, $7.6 \%$ divorced, and $7.6 \%$ widowed. Among the respondents, nearly $62 \%$ reported to having had previous working experience before starting their micro-enterprises. A total of 92 out of 197 respondents reported that they received financial assistance from development organizations.

\subsection{Reliability Analysis}

The Cronbach's Alpha values, as presented in Table 2, for need for achievement, self-efficacy, and experience are more than 0.7 and for risk-taking propensity and micro-enterprise performance, it is more than 0.6. As Cronbach's Alpha for all items are more than 0.6 , this study considered all items as reliable. Moreover, the composite reliability, which takes into account that the indicators have different loadings for all items, is more than 0.8 , which is higher than 0.7 (Hair, Ringle and Sarstedt, 2013), therefore, it is considered as reliable. Convergent validity signifies that a set of indicators represents one and the same underlying construct, which can be demonstrated through their unidimensionality. The average variance extracted (AVE) value for all items is more than 0.5 , which indicates sufficient convergent validity.

Table 1: Respondents' Demographic Characteristics

\begin{tabular}{|c|c|c|c|c|c|}
\hline Gender & $\mathrm{n}$ & $\%$ & Age & $\mathrm{n}$ & $\%$ \\
\hline Male & 99 & $50.3 \%$ & Below 25 years & 66 & $22.3 \%$ \\
\hline Female & 98 & $49.7 \%$ & 25 to 29 years & 62 & $31.5 \%$ \\
\hline \multirow[t]{2}{*}{ Total } & 197 & $100 \%$ & $30-34$ years & 44 & $22.3 \%$ \\
\hline & & & 35 years and above & 47 & $23.9 \%$ \\
\hline Race & $\mathrm{n}$ & $\%$ & Total & 197 & $100 \%$ \\
\hline Malay & 120 & $60.9 \%$ & & & \\
\hline Chinese & 60 & $30.5 \%$ & Marital Status & $\mathrm{n}$ & $\%$ \\
\hline Indian & 4 & $2.0 \%$ & Single & 69 & $35.0 \%$ \\
\hline Others & 13 & $6.6 \%$ & Married & 98 & $49.74 \%$ \\
\hline \multirow[t]{2}{*}{ Total } & 197 & $100 \%$ & Divorce & 15 & $7.6 \%$ \\
\hline & & & Widow & 15 & $7.6 \%$ \\
\hline Work Experience & $\mathrm{n}$ & $\%$ & Total & 197 & $100 \%$ \\
\hline Yes & 122 & $61.9 \%$ & & & \\
\hline No & 75 & 38.1 & Educational Level & $\mathrm{n}$ & $\%$ \\
\hline \multirow{2}{*}{ Total } & 197 & $100 \%$ & UPSR & 13 & $6.6 \%$ \\
\hline & & & PMR & 35 & $17.3 \%$ \\
\hline Financial Support & $\mathrm{n}$ & $\%$ & SPM & 103 & $52.2 \%$ \\
\hline Yes & 92 & 46.7 & STPM and above & 46 & $23.4 \%$ \\
\hline No & 104 & 52.8 & Total & 197 & $100 \%$ \\
\hline Total & 197 & $100 \%$ & & & \\
\hline
\end{tabular}

Table 2: Descriptive and reliability measures

\begin{tabular}{lcccccc}
\hline & \multirow{2}{*}{ Number of Items } & \multicolumn{2}{c|}{ Descriptive } & \multicolumn{3}{c}{ Reliability } \\
\cline { 2 - 6 } & & Mean & S. Deviation & CA & Cl & AVE \\
\hline RTP & 3 & 3.8680 & 0.78069 & 0.673 & 0.812 & 0.594 \\
NFA & 3 & 3.7733 & 0.76222 & 0.700 & 0.832 & 0.623 \\
SEF & 5 & 3.5635 & 0.67573 & 0.781 & 0.850 & 0.531 \\
EXP & 6 & 4.3477 & 0.71404 & 0.895 & 0.917 & 0.650 \\
MEP & 3 & 3.7936 & 0.75234 & 0.649 & 0.802 & 0.578 \\
\hline
\end{tabular}

RTP: Risk-Taking Propensity; NFA: Need for Achievement; SEF: Self-Efficacy; EXP: Experience; MEP: Micro-Enterprise Performance; CA: Cronbach's Alpha, Cl: Composite Reliability; AVE: Average Variance Extracted

Indicators are assumed to be reliable if the absolute standardized outer (component) loadings are higher than 0.7. As noted in Table 3, all items used to measure risk-taking propensity, need for achievement, self-efficacy, experience, and micro-enterprise performance are more than 0.7 , except for the third item of micro-enterprise performance. The crossloading values are far below the outer loadings, which suggest good discriminant validity. The Fornell-Larcker criterion 
assesses the discriminant validity at the construct level. The Fornell-Larcker criterion in Table 3 is largely unable to detect a lack of discriminant validity. Furthermore, the Heterotrait-Monotrait Ratio (HTMT) is an estimate of the correlation between constructs, which parallels the disattenuated construct score creation. Using a value of 0.9 as the threshold, this study concluded that there is no evidence of a lack of discriminant validity.

\subsection{Path Coefficients}

Verifying the reliability and validity of the outer model allowed an evaluation of the inner path model estimates. The coefficient of determination $\left(r^{2}\right)$ of four endogenous latent variables, i.e., risk-taking propensity, need for achievement, self-efficacy, and experience, as shown in Table 4 are considered weak. This moderate $r^{2}$ value is considered as acceptable because this study is not designed to identify which key factor affects micro-enterprise performance; rather, it attempts to identify how risk-taking propensity, need for achievement, self-efficacy, and experience affect microenterprise performance.

Table 3. Outer model loading and cross loading

\begin{tabular}{|c|c|c|c|c|c|}
\hline & RTP & NFA & SEF & EXP & MEP \\
\hline RTP - Q1 & 0.895 & 0.118 & 0.206 & 0.130 & 0.298 \\
\hline RTP - Q2 & 0.693 & 0.061 & 0.065 & 0.176 & 0.137 \\
\hline RTP - Q3 & 0.707 & 0.011 & 0.094 & 0.147 & 0.170 \\
\hline NFA - Q1 & 0.107 & 0.788 & 0.126 & 0.160 & 0.117 \\
\hline NFA - Q2 & -0.008 & 0.757 & 0.043 & 0.089 & 0.129 \\
\hline NFA - Q3 & 0.118 & 0.822 & 0.212 & 0.275 & 0.156 \\
\hline SEF - Q1 & 0.085 & 0.100 & 0.740 & 0.129 & 0.245 \\
\hline SEF - Q2 & 0.147 & 0.128 & 0.729 & 0.024 & 0.263 \\
\hline SEF - Q3 & 0.163 & 0.102 & 0.711 & 0.188 & 0.196 \\
\hline SEF - Q4 & 0.140 & 0.206 & 0.728 & 0.045 & 0.247 \\
\hline SEF - Q5 & 0.122 & 0.060 & 0.736 & 0.017 & 0.207 \\
\hline EXP - Q1 & 0.097 & 0.135 & 0.150 & 0.633 & 0.044 \\
\hline EXP - Q2 & 0.164 & 0.274 & 0.062 & 0.872 & 0.091 \\
\hline EXP - Q3 & 0.139 & 0.113 & 0.008 & 0.785 & 0.071 \\
\hline EXP - Q4 & 0.116 & 0.148 & 0.100 & 0.773 & 0.048 \\
\hline EXP - Q5 & 0.154 & 0.236 & 0.098 & 0.870 & 0.109 \\
\hline EXP - Q6 & 0.177 & 0.174 & 0.113 & 0.876 & 0.141 \\
\hline MEP - Q1 & 0.303 & 0.202 & 0.266 & 0.181 & 0.834 \\
\hline MEP - Q2 & 0.178 & 0.144 & 0.242 & 0.002 & 0.781 \\
\hline MEP - Q3 & 0.116 & -0.015 & 0.226 & 0.044 & 0.653 \\
\hline \multicolumn{6}{|c|}{ Fornell-Larcker Criterion } \\
\hline RTP & 0.771 & & & & \\
\hline NFA & 0.009 & 0.789 & & & \\
\hline SEF & 0.179 & 0.168 & 0.729 & & \\
\hline EXP & 0.182 & 0.230 & 0.106 & 0.806 & \\
\hline MEP & 0.283 & 0.172 & 0.321 & 0.118 & 0.760 \\
\hline \multicolumn{6}{|c|}{ Heterotrait-Monotrait Ratio (HTMT) } \\
\hline \multicolumn{6}{|c|}{ RTP } \\
\hline NFA & 0.114 & & & & \\
\hline SEF & 0.218 & 0.211 & & & \\
\hline EXP & 0.238 & 0.138 & 0.138 & & \\
\hline MEP & 0.352 & 0.212 & 0.444 & 0.112 & \\
\hline
\end{tabular}

RTP: Risk-Taking Propensity; NFA: Need for Achievement; SEF: Self-Efficacy; EXP: Experience; MEP: Micro-Enterprise Performance

The path coefficient between micro-entrepreneurs' 'risk-taking propensity' has a significant (at $5 \%$ level of significance) positive effect on their informal micro-enterprise performance in Malaysia. The informal micro-entrepreneurs' ability to take risks in order to take advantage of short-term income-generating opportunities can therefore be considered as one of the key determinants of their success. Micro-entrepreneurs' need for achievement and experience also has a positive 
effect on micro-enterprise performance. However, the p-values for the coefficients indicate that the effects are not statistically significant. Informal micro-entrepreneurs in Kelantan, Malaysia, share similar economic conditions (from lowincome households) and the types of micro-enterprises they own and manage do not require much expertise, which can be the reason for low and insignificant effect of need for achievement and experience on micro-enterprise performance. The coefficient between self-efficacy and micro-enterprise performance is higher than the other three determinants, which indicates that self-efficacy among informal micro-entrepreneurs plays a crucial role in their micro-enterprise performance. The $p$-value for the path coefficient between self-efficacy and micro-enterprise performance is less than 0.05 , indicating that self-efficacy has a significant effect on informal micro-enterprise performance in Malaysia.

Table 4. Path Coefficients

\begin{tabular}{lccccccc}
\hline & Path Coefficient & $\mathrm{t}$ & $p$ & $r^{2}$ & $f^{2}$ & $\mathrm{Q}^{2}$ & $q^{2}$ \\
\hline $\mathrm{RTP} \rightarrow \mathrm{MEP}$ & 0.222 & 3.218 & 0.001 & & 0.055 & & 0.025 \\
$\mathrm{NFA} \rightarrow \mathrm{MEP}$ & 0.101 & 1.335 & 0.091 & & 0.011 & & 0.004 \\
$\mathrm{SEF} \rightarrow \mathrm{MEP}$ & 0.262 & 3.619 & 0.000 & 0.167 & 0.078 & 0.078 & 0.048 \\
$\mathrm{EXP} \rightarrow \mathrm{MEP}$ & 0.027 & 0.354 & 0.362 & & 0.001 & & 0.001 \\
\hline
\end{tabular}

RTP: Risk-Taking Propensity; NFA: Need for Achievement; SEF: Self-Efficacy; EXP: Experience; MEP: Micro-Enterprise Performance

The effect size $\left(f^{2}\right)$ is calculated as the increase in $r^{2}$ relative to the proportion of variance of the endogenous latent variable that remains unexplained. As shown in Table 4, both significant exogenous latent variables (i.e., risk taking propensity and self-efficacy) have a small effect size, which indicates that besides the selected entrepreneurial competencies, there are other key determinants that affect informal microenterprise performance in Malaysia.

The predominant measure of predictive relevance is Stone-Geisser's $Q^{2}$, which postulates that the model must be able to provide a prediction of the endogenous latent variable's indicators. The $Q^{2}$ value of all endogenous latent constructs, i.e., risk-taking propensity and self-efficacy, are more than 0 , which is indicative of predictive relevance. Moreover, the $q^{2}$ value measures the predictive relevance for exogenous latent variables. As noted in Table 4, the $q^{2}$ values reveal a medium predictive relevance of risk taking propensity and self-efficacy on informal micro-enterprise performance; and need for achievement and experience show a low predictive relevance on informal micro-enterprise performance. However, the $q^{2}$ value for self-efficacy revealed that it has a higher effect on predicting informal microenterprise performance in Malaysia.

\section{Conclusion}

In today's world of inequality, a significant proportion of low-income households in developing countries are actively involved in informal micro-entrepreneurial activities. In Malaysia, a total of 1.3 million workforce $(9.7 \%$ of the total workforce) are involved in informal micro-economic activities. These low-income households are characterized as less educated, possess less enterprise development skills, and commonly do not have access to working capital or enterprise development training. These extremely vulnerable low-income households depend on their micro-enterprise income. It is therefore crucial to examine and identify ways to improve informal micro-enterprise performance, in order to improve the socio-economic conditions of the low-income vulnerable households in Malaysia.

Therefore, this study was designed to examine the role of entrepreneurial competencies, i.e., risk-taking propensity, need for achievement, self-efficacy, and experience in informal micro-enterprise performance in Kelantan, Malaysia. Findings of this study revealed that risk-taking propensity, need for achievement, self-efficacy, and experience have a positive effect on informal micro-enterprise performance. However, only two determinants, i.e., risk-taking propensity and self-efficacy have a significant effect on informal micro-enterprise performance. Informal microentrepreneurs' self-efficacy and ability to take risks in order to take advantage of short-term income-generating opportunities are the key factors that affect informal micro-enterprise performance. Development programs and policies should, therefore, focus on increasing low-income informal micro-entrepreneurs' self-efficacy and ability to take risks to take advantage of all the income-generating opportunities available to them, which would ultimately lead to an improvement in the socio-economic conditions of low-income households in Malaysia. 


\section{References}

Ahmad, N. H., H. A. Halim and S. R. M. Zainal (2010). Is entrepreurial competency the silver bullet for SME success in a developing nation? International Business Management, 4(2): 67-75.

Amurane, A. A. (2007). Legal Mechanisms for the Empowerment of Informal Business. United Nationals Development Programme, National Consultation Reports Series. Maputo, September 2007. Available from: http://www.undp.org/legalempowerment/reports /National\%20Consultation\%20Reports/Country\%20Files/19_Mozam bique/19_6_Informal_Business_Rights.pdf

Andrews, D., Caldera Sánchez, A. and Johansson, A. (2011) Towards a Better Understanding of the Informal Economy, OECD Economics Department Working Papers, No. 873, OECD Publishing

Bird, B. (1995). Towards a theory of entrepreneurial competency. Advances in Entrepreneurship, Firm Emergence and Growth, 2: 51-72.

Brinckmann, J., S. Salomo and H. G. Gemuenden (2011). Financial Management Competence of Founding Teams and Growth of New Technology-Based Firms. Entrepreneurship Theory and Practice, 35(2): 217-243.

Chen, G., Gully, M.S., \& Eden, D. (2004). General self-efficacy and self-esteem: Toward theoretical and empirical distinction between correlated self-evaluations. Journal of Organizational Behavior, 25, 375-395.

Churchill, N. C. and Lewis, V. L. (1983). The five stages of small business growth. Harvard Business Review, 61(1): 30-32.

Department of Statistics Malaysia (2013). Informal Sector Workforce Survey Report Malaysia 2013. Department of Statistics, Malaysia.

Djankov, S., Glaeser, E., LaPorta, R.,Lopez-de-Silanes, F., and Shleifer, A. (2003). A new comparative economics. Journal of Comparative Economy, 31(4): 595-619.

Fernald, L. W., G. T. Soloman and A. Tarabishy (2005). A new paradigm: Entrepreneurial leadership. Southern Business Review, 30(2): $1-13$.

Gerxhani, K. (2009), Informal sector in developed and less developed countries: A literature survey, University of Amsterdam Working Paper series. University of Amsterdam.

Hair J. F. Jr., Ringle, C. M. and Sarstedt, M. (2013) Partial Least Squares Structural Equation Modeling: Rigorous Applications, Better Results and Higher Acceptance, Long Range Planning 46: 1-12

Hansemark O. C. (1998), The effects of an entrepreneurship program on need for achievement and locus of control of reinforcement, International Journal of Entrepreneurial Behavior and Research, 4(1): 28-50.

Hansemark, O.C. (2003). Need for Achievement, Locus of Control and the Prediction of Business Start-Ups: A Longitudinal Study. Journal of Economic Psychology, 24, 301-319.

Islam, M.A., Khan, M.A., Obaidullah, A.Z.M \& Alam, M.S. (2011). Effect of entrepreneur and firm characteristics on the business success of small and medium enterprises (SMEs) in Bangladesh. International Journal of Business and Management, 6(3), $289-299$.

Landqvist, $H$. and P. Stålhandske (2011). Risk propensity of entrepreneurs-A study of underlying factors in background and personality in comparison with managers. Management \& Organization Report No. 11: 64, Göteborgs Universitet, Sweden

Lerner, M. and Almor, T. (2002). Relationships among strategic capabilities and the performance of women-owned small ventures. Journal of Small Business Management, 40(2): 109-125.

Luthans, F. and Ibrayeva, E. S. (2006). Entrepreneurial self-efficacy in Central Asian transition economies: quantitative and qualitative analyses. Journal of International Business Studies, 37(1): 92-110.

Man, T. W. Y. and T. Lau (2000). Entrepreneurial competencies of SME owner/managers in the Hong Kong services sector: A qualitative analysis. Journal of Enterprising Culture, 8(3): 235-254.

Man, T. W. Y., T. Lau and K. F. Chan (2002). The competitiveness of small and medium enterprises: a conceptualization with focus on entrepreneurial competencies. Journal of Business Venturing, 17(2): 42-123.

Martin, G. and Staines, H. (1994). Managerial competences in small firms. Journal of Management Development, 13(7): $23-34$.

Mitchelmore, S. and Rowley, J. (2013). Entrepreneurial competencies of women entrepreneurs pursuing business growth. Journal of Small Business and Enterprise Development, 20(1): 125-142.

Naik, A. K. (2009). Informal sector and informal workers in India. In: Special IARIW-SAIM Conference on 'Measuring the Informal Economy in Developing Countries' September 23-26, 2009 Kathmandu, Nepal.

Nichter, S. and Goldmark, L. (2009). Small Firm Growth in Developing Countries. World Development, 37(9): 1453-1464

Sagie, A. and Elizur, D. (1999) Achievement motive and entrepreneurial orientation: a structural analysis, Journal of Organizational Behavior, 20(3): 375-387,

Shepherd, D. A., A. Zacharakis and R. A. Baron (2003). VCs' decision processes: Evidence suggesting more experience may not always be better. Journal of Business Venturing, 18(3): 381-401.

Shepherd, D.A., Douglas, E.J., and Shanley, M. (2000). New Venture Survival: Ignorance, External Shocks, and Risk Reduction Strategies. Journal of Business Venturing, 15(5-6), 393- 410.

Sibal, J. V. (2007). Measuring the informal sector in the Philippines and the trends in Asia. In: 10th National Convention on Statistics, October 1-2, Shangri-La Hotel. Mandaluyong City, Philippines

Thompson, B. (1998). In praise of brilliance: Where that praise really belongs. American Psychologist, 53(7): 799-800.

Tokman, V. E. (2001). Integrating the informal sector in the modernization process. SAIS Review, 21(1): 45-60.

Tull, M. T., Trotman, A., Duplinsky, M. S., Reynolds, E. K., Daughters, S. B., Potenza, M. N., and Lejuez, C. W. (2009). The effect of posttraumatic stress disorder on risk-taking propensity among crack/cocaine users in residential substance abuse treatment. Depression and Anxiety, 26(12): 1158-1164.

Webb, J. W., Bruton, G. D., Tihanyi, L. and Ireland, R. D. (2013) Research on entrepreneurship in the informal economy: Framing a 
research agenda, Journal of Business Venturing, 28(5): 598-614

Williams, C.C. and Gurtoo, A. (2011). Evaluating women entrepreneurs in the informal sector: some evidence from India. Journal of Developmental Entrepreneurship, 16(3): 351-369.

Willebrands, D., J. Lammers and J. Hartog (2012). A successful businessman is not a gambler. Risk attitude and business performance among small enterprises in Nigeria. Journal of Economic Psychology, 33(2): 342-354.

Winterton, J. and J. Winterton (2009). Competence across Europe: highest common factor or lowest common denominator? Journal of European Industrial Training, 33(8/9): 681-700.

Yusuf, A. (1995). Critical success factors for small business: perceptions of South Pacific entrepreneurs. Journal of Small Business Management, 33: 2-68.

Zhao, H., Seibert, S. E., and Lumpkin, G. T. (2010). The relationship of personality to entrepreneurial intentions and performance: A meta-analytic review. Journal of Management, 36, 381-404. 